\title{
A reminder on superior herniation of normal mediastinal thymus
}

\author{
Saliha Senel
}

Received: 5 November 2010 / Accepted: 18 January 2011 / Published online: 8 February 2011

(C) Springer-Verlag 2011

\section{Dear Editor,}

We read with interest the article "Inspiratory stridor and dysphagia in two newborn infants caused by ectopic thymus tissue" in the September 2009 issue of the European Journal of Pediatrics [1]. This has caused us to remind that "superior herniation of normal mediastinal thymus" or "thymic herniation" is an entity defined as intermittent migration of the normal thymus out of the thorax into the suprasternal region during increased intrathoracic pressure caused by coughing, sneezing, crying, and Valsalva maneuver [2]. As the authors mentioned, surgical removal and histological examination is often the only way to prove the diagnosis of ectopic thymic masses, so to avoid unnecessary biopsy or surgery, it is very important to identify and differentiate thymic herniation from other neck masses especially from ectopic thymic masses because it is only normal thymic tissue and necessary for the maintenence of normal immune function in children. Pediatricians, radiologists, and especially surgeons should be aware of this entity so as not to give harm to the children.

\section{References}

1. Felgentreff K, Schupp W, Otten JE et al (2009) Inspiratory stridor and dysphagia in two newborn infants caused by ectopic thymus tissue. Eur J Pediatr 168:1141-1145

2. Senel S, Erkek N, Otgun I et al (2008) Superior herniation of the thymus into the neck-a familial pattern. J Thorac Imaging 23:131-134
S. Senel $(\bowtie)$

Department of Pediatrics, Dr. Sami Ulus Maternity and Children's Health and Diseases Training and Research Hospital,

Ankara, Turkey

e-mail: drsaliha007@yahoo.com.tr 